\title{
Theoretical and Experimental Insights into the Tandem Mannich-Electrophilic Amination Reaction: Synthesis of Safirinium Dyes
}

\author{
Jarosław Sączewski $^{1, * \mathbb{D}}$, Joanna Fedorowicz ${ }^{2} \mathbb{D}$, Paulina Wiśniewska ${ }^{1}$ and Maria Gdaniec ${ }^{3}(\mathbb{D}$ \\ 1 Department of Organic Chemistry, Faculty of Pharmacy, Medical University of Gdansk, \\ 107 Gen. J. Hallera Av., 80-416 Gdansk, Poland; paulina.wisniewska@gumed.edu.pl \\ 2 Department of Chemical Technology of Drugs, Faculty of Pharmacy, Medical University of Gdansk, \\ 107 Gen. J. Hallera Av., 80-416 Gdansk, Poland; joanna.fedorowicz@gumed.edu.pl \\ 3 Faculty of Chemistry, Adam Mickiewicz University, 61-614 Poznan, Poland; magdan@amu.edu.pl \\ * Correspondence: js@gumed.edu.pl
}

Citation: Sączewski, J.; Fedorowicz, J.; Wiśniewska, P.; Gdaniec, M.

Theoretical and Experimental Insights into the Tandem Mannich-

Electrophilic Amination Reaction: Synthesis of Safirinium Dyes. Appl. Sci. 2021, 11, 5498. https://doi.org/ 10.3390/app11125498

Academic Editor: Mariusz Mojzych

Received: 23 May 2021

Accepted: 10 June 2021

Published: 14 June 2021

Publisher's Note: MDPI stays neutral with regard to jurisdictional claims in published maps and institutional affiliations.

Copyright: (c) 2021 by the authors. Licensee MDPI, Basel, Switzerland. This article is an open access article distributed under the terms and conditions of the Creative Commons Attribution (CC BY) license (https:// creativecommons.org/licenses/by/ $4.0 /)$.

\begin{abstract}
Isoxazolo[3,4- $b$ ]pyridin-3(1H)-ones are 'spring-loaded' compounds that quantitatively react with iminium salts derived from formaldehyde and secondary amines to yield fluorescent Safirinium dyes. The mechanism and energetics of the above tandem Mannich-electrophilic amination reaction have been investigated experimentally and using theoretical methods. The hybrid B3LYP functional with GD3 empirical dispersion and range-separated hybrid functional $\omega \mathrm{B} 97 \mathrm{XD}$, both combined with a PCM model, were applied to acquire the energetic profiles of the studied reaction with respect to the structure of secondary amine and isoxazolone used. Diastereoselectivity of the tandem reactions involving iminium salt derived from L-proline has been rationalized theoretically by means of density functional theory calculations.
\end{abstract}

Keywords: cationic dyes; DFT; electrophilic amination; isoxazolone; Mannich reaction; spring-loaded reactants; triazolinium salts; tandem reaction; theoretical calculations

\section{Introduction}

The chemical reactions that feature pure kinetic-control of the outcome and utilize 'spring-loaded' reactants are of considerable interest in multiple applications that include drug discovery, combinatorial chemistry, target-templated in situ chemistry, proteomics, DNA research and bioconjugation techniques [1]. The commonly recognized high yielding, thermodynamically favored and wide-in-scope reactions, such as nucleophilic ring opening reactions of epoxides and aziridines, non-aldol type carbonyl reactions, and additions to carbon-carbon multiple bonds, have been termed by K. B. Sharpless as "click chemistry" [2].

In the above context we have recently developed the tandem Mannich-electrophilic amination reaction of fluorogenic 4,6-dimethylisoxazolo[3,4- $b]$ pyridin-3(1H)-one or isoxa zolo[3,4- $b]$ quinolin-3(1H)-one with formaldehyde and secondary amines that leads to zwitterionic UV-fluorescent Safirinium P and Q dyes, respectively [3,4]. The latter upon esterification with $N$-hydroxy-succinimide (NHS) can serve as fluorescent amine-reactive reagents which are useful as fixed charge derivatization reagents for micellar electrokinetic chromatography (MEKC) and MS proteomic analyses [5], as well as for bioimaging purposes such as stanning of bacterial cells and spores $[4,6,7]$. The tandem reactions of non-fluorescent isoxazolones, formaldehyde and secondary amines, i.e., syntheses of Safirinium dyes, proceed quantitatively, however the reaction rates strongly depend on the substitution pattern, which results in reaction times ranging from several minutes to dozens of hours [4]. The aim of the present study was to describe the tandem Mannichelectrophilic amination reactions using commonly recognized theoretical quantum chemical methods [8-10] and identify the steric factors that would limit applications of these pro- 
cesses in a fast and sensitive detection of formaldehyde and fluorescent derivatization of secondary aliphatic amines.

\section{Results and Discussion}

First, we have proved that 4,6-dimethylisoxazolo[3,4-b]pyridin-3(1H)-one (1) undergoes 1,2 nucleophilic addition in a reaction with formaldehyde to afford hemiaminal 2, the structure of which was unambiguously confirmed by single crystal X-ray analysis (Figure 1). According to our previous studies, the same reaction performed in the presence of secondary amine $\left(\mathrm{HNR}^{1} \mathrm{R}^{2}\right)$ gives rise to the formation 2,2-dialkyl-5,7-dimethyl-2,3dihydro-[1,2,4]triazolo[4,3-a]pyridin-2-ium-8-carboxylates (3a,b), i.e., Safirinium P dyes, by means of the tandem Mannich-electrophilic amination reaction [4]. Hence, acidic isoxazolone $\mathbf{1}$ in the presence of a base forms salts $\mathbf{1 a}, \mathbf{b}$ which further react with formaldehyde to yield iminium salts $\mathbf{1 a}, \mathbf{b}$. Furthermore, the ambident nucleophile and iminium cations give the Mannich addition products (aminals $\mathbf{1 a}, \mathbf{b}$ ) that spontaneously undergo electrophilic amination reactions via the transition states $\mathbf{1} \mathbf{a}, \mathbf{b}$ affording products $\mathbf{3} \mathbf{a}, \mathbf{b}$ in $\mathbf{a}$ quantitative manner.

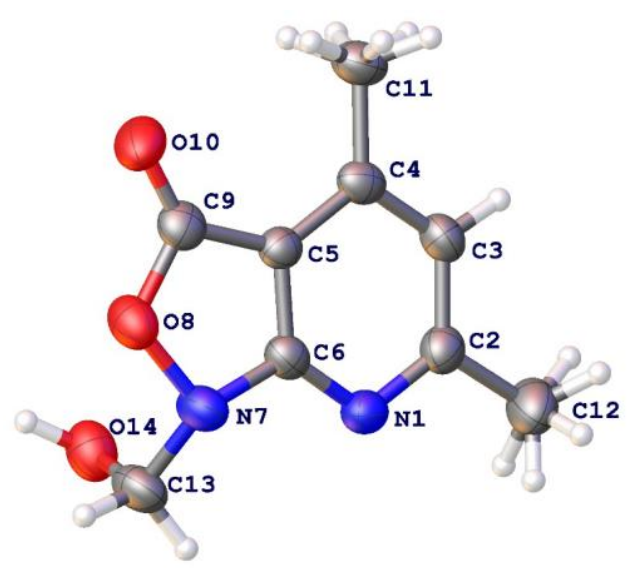

Figure 1. Molecular structure of 2. Displacement ellipsoids are shown at the 50\% probability level.

In order to get a better insight into the above chemical transformations, we have performed theoretical studies with use of DFT B3LYP [11] and $\omega$ B97X-D [12] methods as well as a Polarizable Continuum Model (IEF-PCM) [13] implemented in a Gaussian 16 software package [14]. The stationary structures that pertain to the chemical entities presented in Scheme 1 were optimized to confirm that all ground structures, except for the transition states, have only real frequencies. The relative energy comparisons in water and methanol solutions are given in Table 1. As a general observation, pure B3LYP/PCM density functional without empirical dispersion failed to reasonably reproduce the investigated chemical transformations since the reaction products $\mathbf{2}$ and $\mathbf{3} \mathbf{a}, \mathbf{b}$ were found to be thermodynamically unfavorable in water and methanol with the Gibbs free energies for the latter solvent of $0.6,5.8$, and $0.3 \mathrm{kcal} / \mathrm{mol}$, respectively. This theoretical approach predicted also relatively high energy barriers for the electrophilic amination processes by means of high Gibbs free energies of 28.4 and $22.7 \mathrm{kcal} / \mathrm{mol}$ for the transition states $\mathbf{1 a}, \mathbf{b}$ in methanol. Since the correct determination of large molecular structures and their properties require inclusion of the van der Waals interactions between molecules, we have added to the B3LYP/6-31+G(d) functional Grimme's empirical dispersion corrections [15], which were found to reliable in describing large molecular systems [16]. Consequently, the results obtained show that formation Safirinum $P$ dye (3a) is thermodynamically favorable with $\Delta \mathrm{G}$ values of -4.0 and $-3.1 \mathrm{kcal} / \mathrm{mol}$ for reactions carried in water and methanol, respectively. Similarly, the application of dispersion corrections significantly lowered the calculated electrophilic amination barriers revealing transition states with $\Delta \mathrm{G}$ values of 19.1 and $19.5 \mathrm{kcal} / \mathrm{mol}$. The reaction of sterically constrained 1-methylenepyrrolidinium salt $\mathbf{1 b}$ 
is considerably faster and more exothermic than that involving unconstrained iminium salt 1a (19.5 vs. $15.8 \mathrm{kcal} / \mathrm{mol}$ and $-3.1 \mathrm{vs}$. $-7.6 \mathrm{kcal} / \mathrm{mol})$. Finally, utilization of larger basis set, i.e., $6-311+\mathrm{G}(\mathrm{d}, \mathrm{p})$, or application of a range-separated hybrid functional $\omega B$ B7X-Dand results in a further reduction of the discussed $\Delta \mathrm{G}$ values by ca. $4 \mathrm{kcal} / \mathrm{mol}$.

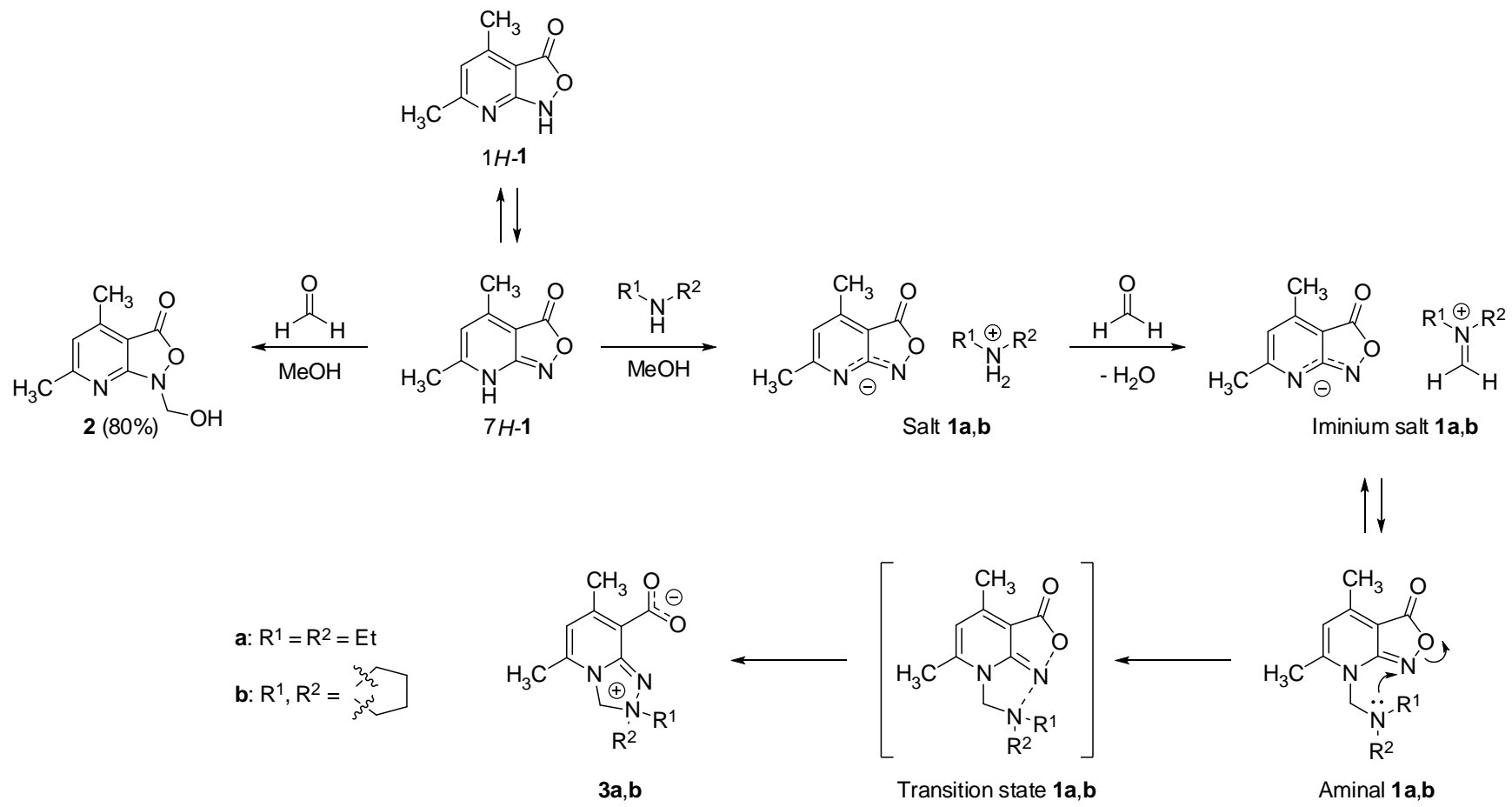

Scheme 1. The reaction of isoxazolone $\mathbf{1}$ with formaldehyde and synthesis of Safirinium P dyes $\mathbf{3 a}, \mathbf{b}$ by means of the tandem Mannich-electrophilic amination reaction.

Table 1. The relative electronic (plain text) and Gibbs free (italics) energies ( $\mathrm{kcal} / \mathrm{mol}$ ) of subsequent stages of the tandem Mannich-electrophilic amination reactions calculated by DFT/PCM methods.

\begin{tabular}{|c|c|c|c|c|c|c|c|c|c|}
\hline $\begin{array}{l}\text { Reaction } \\
\text { Product and } \\
\text { Solvent }\end{array}$ & $\begin{array}{c}\text { DFT/ } \\
\text { Basis Set }\end{array}$ & $1 H-1$ & $7 H-1$ & 2 & Salt 1 & $\begin{array}{l}\text { Iminium } \\
\text { Salt } 1\end{array}$ & Aminal 1 & $\begin{array}{c}\text { Transition } \\
\text { State } 1\end{array}$ & 3 \\
\hline \multirow{6}{*}{$\begin{array}{c}3 \mathrm{a} \\
\mathrm{H}_{2} \mathrm{O}\end{array}$} & B3LYP/ & 0.4 & 0 & -13.6 & 2.1 & 5.6 & -5.0 & 11.6 & -11.8 \\
\hline & $6-31+G(d)$ & 0.4 & 0 & 1.0 & 3.8 & 8.6 & 11.9 & 28.2 & 5.2 \\
\hline & B3LYP-D3/ & 0.5 & 0 & -16.5 & 1.8 & 4.5 & -13.6 & 1.9 & -21.7 \\
\hline & $6-31+G(d)$ & 0.5 & 0 & -1.8 & 3.9 & 7.5 & 3.2 & 19.1 & -4.0 \\
\hline & B3LYP-D3/ & 0.3 & 0 & -17.1 & 3.1 & 1.4 & -16.4 & -0.9 & -24.9 \\
\hline & $6-311+G(d, p)$ & 0 & 0.9 & -2.6 & 4.9 & 4.3 & 1.0 & 16.1 & -7.0 \\
\hline \multirow{4}{*}{$\begin{array}{c}3 a \\
\mathrm{MeOH}\end{array}$} & B3LYP/ & 0.2 & 0 & -13.9 & 3.8 & 7.3 & -5.0 & 11.8 & -11.0 \\
\hline & $6-31+G(d)$ & 0 & 0 & 0.6 & 6.6 & 10.2 & 11.7 & 28.4 & 5.8 \\
\hline & B3LYP-D3/ & 0.3 & 0 & -16.8 & 3.5 & 6.1 & -17.7 & 2.2 & -20.8 \\
\hline & $6-31+G(d)$ & 0.4 & 0 & -2.0 & 6.0 & 9.3 & 3.7 & 19.5 & -3.1 \\
\hline \multirow{4}{*}{$\begin{array}{c}3 b \\
\mathrm{MeOH}\end{array}$} & B3LYP/ & 0.2 & 0 & -13.9 & 3.1 & 3.2 & -10.4 & 7.1 & -16.0 \\
\hline & $6-31+G(d)$ & 0 & 0 & 0.6 & 6.1 & 5.4 & 5.3 & 22.7 & 0.3 \\
\hline & B3LYP-D3/ & 0.3 & 0 & -16.8 & 3.1 & 2.6 & -17.4 & -0.9 & -24.1 \\
\hline & $6-31+G(d)$ & 0.4 & 0 & -2.0 & 6.3 & 5.2 & -0.9 & 15.8 & -7.6 \\
\hline \multirow{4}{*}{$\begin{array}{c}3 \mathbf{a} \\
\mathrm{H}_{2} \mathrm{O}\end{array}$} & $\omega B 97 X-D a n d /$ & 0 & 0.1 & -19.7 & 1.5 & 3.9 & -18.6 & 3.6 & -27.4 \\
\hline & $6-31+G(d)$ & 0 & 1.0 & -4.8 & 3.1 & 7.0 & -0.1 & 21.3 & -8.6 \\
\hline & $\omega B 97 X-D a n d /$ & 0 & 0.3 & -20.4 & 2.9 & 1.2 & -21.5 & 0.8 & -30.7 \\
\hline & $6-311+G(d, p)$ & 0 & 1.5 & -6.3 & 4.1 & 3.6 & 3.7 & 17.9 & -13.3 \\
\hline $3 a$ & $\omega B 97 X-D a n d /$ & 0 & 0.3 & -20.1 & 3.4 & 5.6 & -18.5 & 3.9 & -26.5 \\
\hline $\mathrm{MeOH}$ & $6-31+G(d)$ & 0 & 1.2 & -6.2 & 6.6 & 8.8 & 0 & 21.7 & -8.7 \\
\hline
\end{tabular}


It should be pointed out that in all cases, except for pure B3LYP functional, the formation of product 3 is thermodynamically favoured over the reversible production of hemiaminal 2. Moreover, the heterocyclic system of $\mathbf{2}$ is virtually planar with the amino N7 atom of the 5-isoxazolone fragment showing a pyramidal arrangement of its bonds with the sum of the three valence angles equal to $334.4^{\circ}$. This value is consistent with relatively long bonds formed by N7 to O8 and C6 (1.446 and $1.393 \AA$, respectively). Our survey of the Cambridge Structural Database (CSD) [17] showed that for N-substituted 5-isoxasolones the N-C bond lengths range from 1.33 to $1.43 \AA$. Such a broad range of the values shows that the amino $\mathrm{N}$ atom can with ease change its hybridization state.

In our previous work, we have reported that isoxazolone 1 reacts with iminium salt derived from L-proline only in the presence of a base, e.g., triethylamine (Scheme 2) [5]. Hence, the investigated tandem reaction is a base-promoted process, which in the case of L-proline transformation leads to single diastereoisomer $\mathbf{3 c}$.

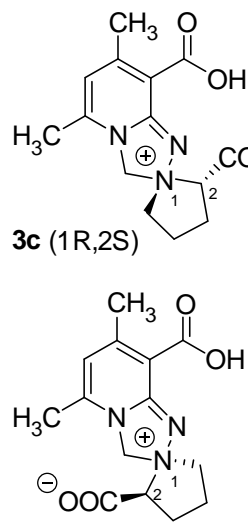

$3 c(1 \mathrm{~S}, 2 \mathrm{~S})$<smiles>C[C@H](C=O)C(C)(C)C</smiles><smiles>CCCCNC(=O)n1[nH]c(=O)c2c(C)cc(C)nc21</smiles>

Salt $1 c$

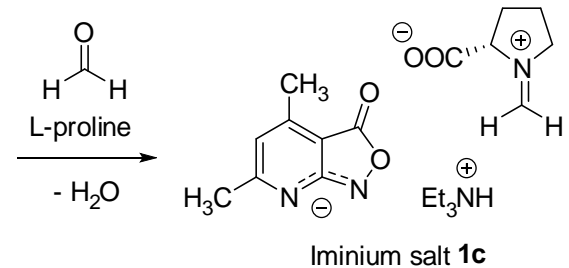
$-\mathrm{Et}_{3} \stackrel{\oplus}{\mathrm{NH}} \uparrow \uparrow$<smiles></smiles>

$3 c(1 \mathrm{R}, 2 \mathrm{~S})$

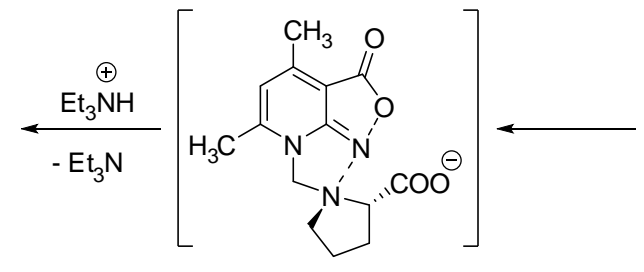

Transition state 1c (1R,2S)<smiles>Cc1cc(C)n(CN2CCCC2)c2nc(=O)ncc1-2</smiles>

Aminal 1c $(1 \mathrm{R}, 2 \mathrm{~S})$

Scheme 2. The base promoted tandem reaction of isoxazolone 1 with iminium salt derived from L-proline and formaldehyde.

In order to investigate the nature of the diastereospecific reaction, we have completed theoretical calculations for the reaction paths that lead to both products. Surprisingly, it was found that the thermochemical factors do not favor formation of any of the examined diastereoisomers 3c (Table 2).

Table 2. The relative electronic (plain text) and Gibbs free (italics) energies ( $\mathrm{kcal} / \mathrm{mol}$ ) of subsequent stages of the tandem Mannich-electrophilic amination reactions calculated by B3LYP and B3LYP-D3 methods.

\begin{tabular}{|c|c|c|c|c|c|c|c|}
\hline $\begin{array}{l}\text { Reaction } \\
\text { Product and } \\
\text { Solvent }\end{array}$ & $\begin{array}{c}\text { DFT/ } \\
\text { Basis Set }\end{array}$ & $7 H-1 c$ & Salt 1c & $\begin{array}{l}\text { Iminium } \\
\text { Salt 1c }\end{array}$ & Aminal 1c & $\begin{array}{c}\text { Transition } \\
\text { State 1c }\end{array}$ & $3 c$ \\
\hline \multirow{4}{*}{$\begin{array}{c}3 \mathrm{c}(1 \mathrm{R}, 2 \mathrm{~S}) \\
\mathrm{MeOH}\end{array}$} & B3LYP/ & 0 & 2.7 & 7.5 & 0 & 16.8 & -4.7 \\
\hline & $6-31+G(d)$ & 0 & 6.7 & 10.4 & 10.4 & 34.2 & 10.6 \\
\hline & B3LYP-D3/ & 0 & 1.9 & 5.5 & -7.2 & 11.6 & -14.7 \\
\hline & $6-31+G(d)$ & 0 & 6.1 & 8.8 & 6.9 & 26.3 & 1.8 \\
\hline \multirow{4}{*}{$\begin{array}{c}3 \mathrm{c}(1 \mathrm{~S}, 2 \mathrm{~S}) \\
\mathrm{MeOH}\end{array}$} & B3LYP/ & 0 & 3.1 & 7.5 & 0.9 & 19.4 & -4.4 \\
\hline & $6-31+G(d)$ & 0 & 6.1 & 10.4 & 14.3 & 35.9 & 10.9 \\
\hline & B3LYP-D3/ & 0 & 3.1 & 5.5 & -7.6 & 10.7 & -14.5 \\
\hline & $6-31+G(d)$ & 0 & 6.3 & 8.8 & 6.8 & 27.0 & 1.9 \\
\hline
\end{tabular}


These results prompted us to investigate the structure of iminium zwitterion $1 \mathrm{c}$ using quantum chemical calculations (B3LYP/6-31+G(d)). As shown in Figure 2, the highest densities of the lowest unoccupied orbital (LUMO) can be found on the iminium carbon atom. However, the carboxylate group strongly affects the topicity of this atom favoring Re-face reactivity that results in formation of $1 \mathrm{R}, 2 \mathrm{~S}$ diastereoisomer $3 \mathrm{c}$. An extensive literature review has confirmed the proposed reasoning. Thus, 1-[(2-hydroxy-1-naphthyl)methyl]proline, obtained via Mannich-type condensation from $\beta$-naphthol, L-proline and formaldehyde, reacts with boron compounds with high diastereoselectivity [18].
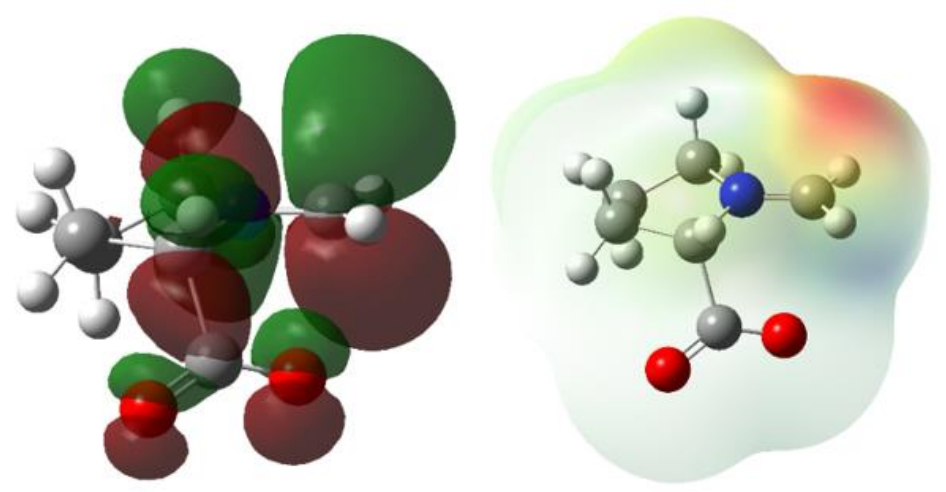

Figure 2. The lowest unoccupied orbital $(\mathrm{LUMO})($ isoval $=0.02)$ and electron density $($ isoval $=0.0004)$ mapped with LUMO density calculated for the iminium zwitterion 1c.

Next, we examined the reaction path that results in formation of 2,2-diethyl-1,2dihydro-[1,2,4]triazolo[4,3-a]quinolin-2-ium-4-carboxylate (6), i.e., Safirinium Q dye (Scheme 3). The results obtained clearly indicate that isoxazolo[3,4-b]quinolin-3(1H)-one (4) is more reactive than 4,6-dimethylisoxazolo[3,4-b]pyridin-3(1H)-one (1) with respect to the tandem Mannich-electrophilic amination process. Hence, the calculated transition state energy barrier amounts to 14.3 or $16.2 \mathrm{kcal} / \mathrm{mol}$ in water and 14.4 or $16.7 \mathrm{kcal} / \mathrm{mol}$ in methanol, when estimated with B3LYP-D3 and $\omega$ B97X-Dand methods, respectively (Table 3). These values are ca. $4 \mathrm{kcal} / \mathrm{mol}$ lower than those estimated for the transition state 1a. Analogous tendencies can be observed when comparing the estimated Gibbs free energies for products $\mathbf{3} \mathbf{a}$ and $\mathbf{6}$.

Table 3. The relative electronic (plain text) and Gibbs free (italics) energies ( $\mathrm{kcal} / \mathrm{mol}$ ) of subsequent stages of the tandem Mannich-electrophilic amination reaction calculated by DFT/PCM methods.

\begin{tabular}{|c|c|c|c|c|c|c|c|c|c|}
\hline Solvent & $\begin{array}{c}\text { DFT/ } \\
\text { Basis Set }\end{array}$ & $1 H-4$ & $9 H-4$ & 5 & Salt 4 & $\begin{array}{l}\text { Iminium } \\
\text { Salt } 4\end{array}$ & Aminal 4 & $\begin{array}{c}\text { Transition } \\
\text { State } 4\end{array}$ & 6 \\
\hline \multirow{4}{*}{$\mathrm{H}_{2} \mathrm{O}$} & B3LYP/ & 1.9 & 0 & -11.8 & 2.9 & 6.5 & -5.1 & 7.4 & -17.3 \\
\hline & $6-31+G(d)$ & 1.9 & 0 & 2.7 & 3.6 & 8.5 & 11.0 & 23.0 & -0.8 \\
\hline & B3LYP-D3/ & 2.4 & 0 & -14.7 & 3.0 & 5.7 & -13.5 & -1.4 & -26.7 \\
\hline & $6-31+G(d)$ & 2.3 & 0 & 0 & 3.9 & 7.6 & 3.0 & 14.3 & -9.0 \\
\hline \multirow{4}{*}{$\mathrm{MeOH}$} & B3LYP/ & 2.2 & 0 & -11.9 & 5.0 & 8.5 & -4.7 & 8.0 & -16.1 \\
\hline & $6-31+G(d)$ & 2.1 & 0 & 2.6 & 6.9 & 10.5 & 11.4 & 23.6 & 0.5 \\
\hline & B3LYP-D3/ & 2.2 & 0 & -14.9 & 4.7 & 7.3 & -25.9 & -1.2 & -25.9 \\
\hline & $6-31+G(d)$ & 2.2 & 0 & -0.2 & 5.9 & 9.2 & -8.2 & 14.4 & -8.2 \\
\hline \multirow{2}{*}{$\mathrm{H}_{2} \mathrm{O}$} & $\omega B 97 X-D a n d /$ & 2.1 & 0 & -17.5 & 3.2 & 5.7 & -18.3 & -0.1 & -26.7 \\
\hline & $6-31+G(d)-$ & 2.1 & 0 & -2.7 & 4.0 & 7.5 & -1.3 & 16.2 & -9.0 \\
\hline \multirow{2}{*}{$\mathrm{MeOH}$} & $\omega B 97 X-D a n d /$ & 2.4 & 0 & -17.4 & 4.2 & 7.6 & -18.1 & 0.3 & -31.5 \\
\hline & $6-31+G(d)-$ & 2.4 & 0 & -2.5 & 6.1 & 9.4 & -1.0 & 16.7 & -13.5 \\
\hline
\end{tabular}


<smiles>O=c1o[nH]c2nc3ccccc3cc12</smiles><smiles>O=c1on(CO)c2nc3ccccc3cc12</smiles><smiles>CC=O</smiles><smiles>O=c1onc2[nH]c3ccccc3cc1-2</smiles><smiles>CCNCC</smiles><smiles>CCN[NH2+]CC</smiles><smiles>CC=O</smiles>
Salt 4<smiles></smiles><smiles></smiles>

6

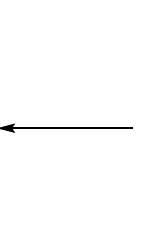

Transition state $\mathbf{4}$

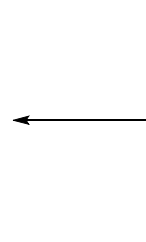<smiles>CCN(CC)Cn1c(=O)ncc2cc3ccccc3nc21</smiles>

Aminal 4

Scheme 3. The reaction of isoxazolone 4 with formaldehyde and synthesis of Safirinium Q dye 6 by means of the tandem Mannich-electrophilic amination reaction.

It should be pointed out that the obtained theoretical evaluations match the observed chemical experiments. According to our previous report, reactions involving isoxazolone $\mathbf{1}$ are rather slow and require heat $[4,19]$. Conversely, tandem transformations involving isoxazolone 4 are fast (Figure 3).

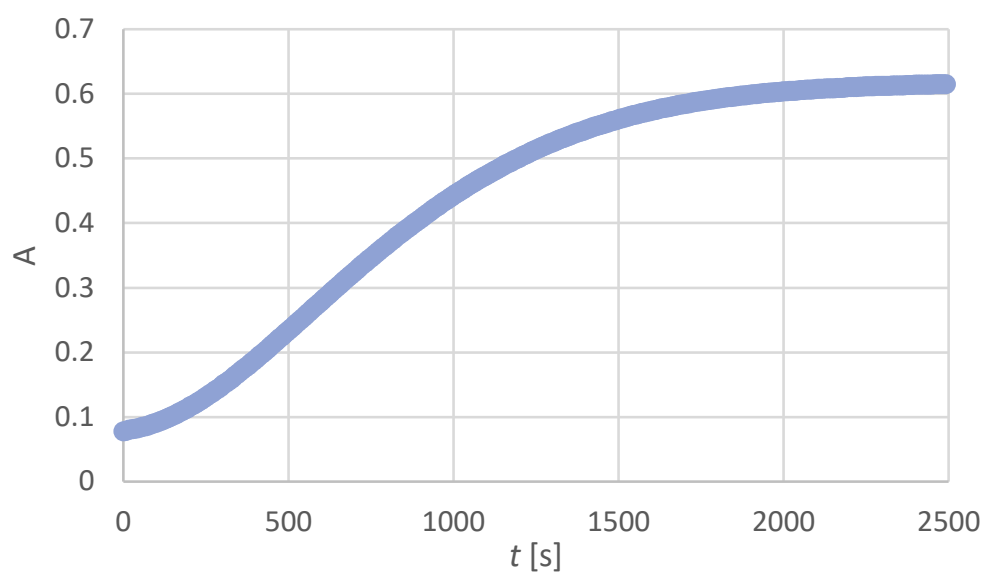

Figure 3. The formation of Safirinium $Q$ (6) from equimolar quantities $(0.6 \mathrm{mmol} / \mathrm{L})$ of isoxazolone 4, formaldehyde and diethylamine (absorbance at $370 \mathrm{~nm}$ vs. time).

Finally, we have evaluated the scope of the tandem reaction in terms of steric factors that would limit its applications. As shown in Scheme 4, isoxazolone 4 has been subjected to reactions with piperazine, homopiperazine and two $N, N^{\prime}$-dialkylethylenediamines. Hence, the reaction with the most sterically constrained piperazine gave rise to the formation of a mono-derivative, i.e., $1 H$-spiro[1,2,4]triazolo[4,3-a]quinoline-2,1'-piperazin]-2-ium-4carboxylate (7) as a single product. On the contrary, the reactions with less constrained diamines produced double Mannich-amination products $\mathbf{8 a}, \mathbf{b}$ and $\mathbf{9}$. In order to rationalize the difference in reactivity of piperazine and homopiperazine we have performed theoretical computations, analogical to the experiments presented above. 


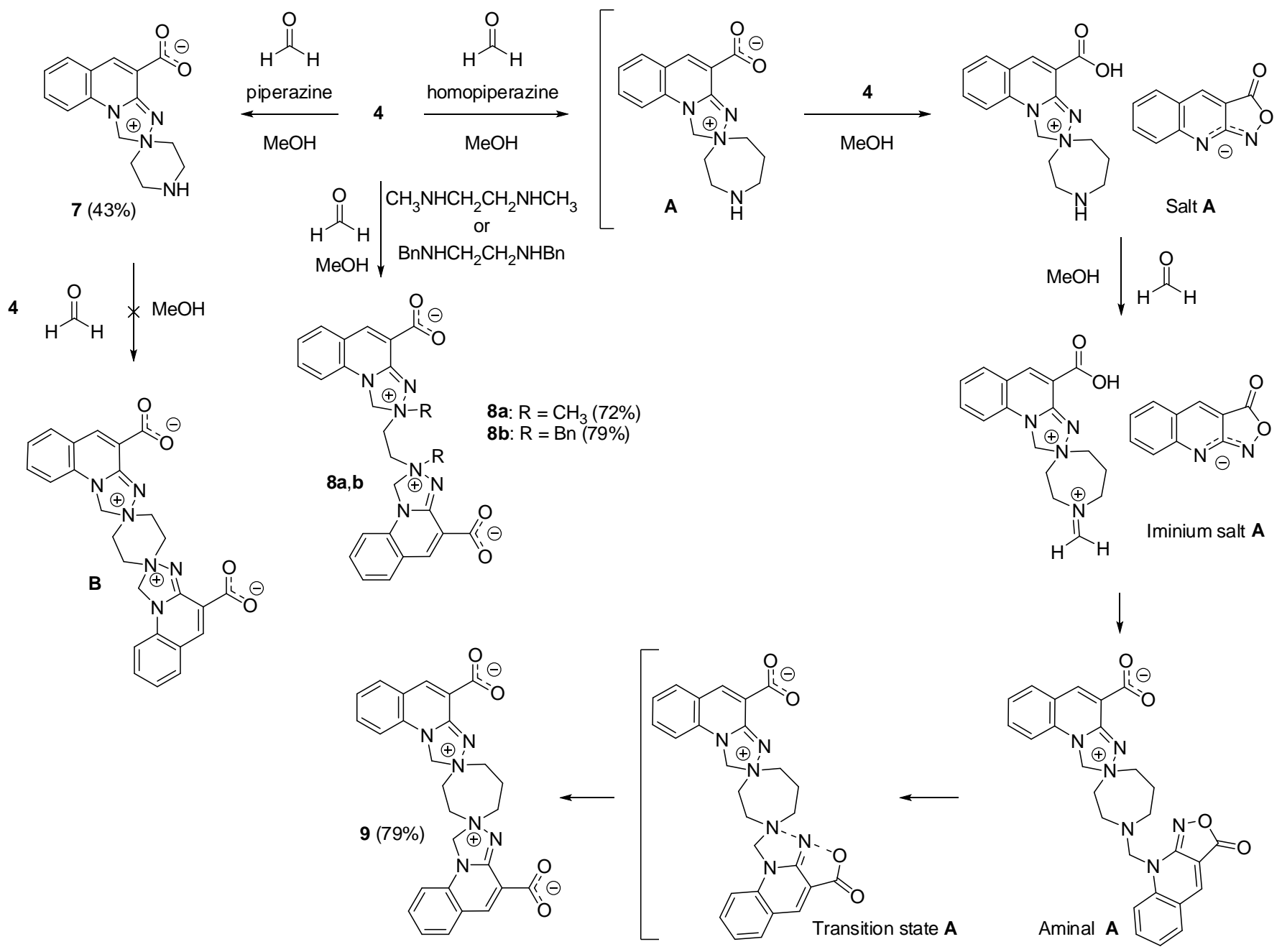

Scheme 4. The reaction of isoxazolone 4 with with iminium salts derived from piperazine, homopiperazine and $N^{1}, N^{2}-$ dibenzylethane-1,2-diamine.

Albeit, the energy barriers for transformations A $->9$ and 7 -> B were found to be comparable, the formation of product $\mathbf{B}(4.8$ and $-0.5 \mathrm{kcal} / \mathrm{mol})$ was estimated to be thermodynamically unfavored in comparison to the homopiperazine derivative 9 (1.3 and $-3.6 \mathrm{kcal} / \mathrm{mol}$ ) (Table 4).

Table 4. The relative electronic (plain text) and Gibbs free (italics) energies (kcal/mol) of subsequent stages of the tandem Mannich-electrophilic amination reactions calculated by DFT/PCM methods.

\begin{tabular}{|c|c|c|c|c|c|c|c|}
\hline Reaction & $\begin{array}{c}\text { DFT/ } \\
\text { Basis Set }\end{array}$ & Zwitterion & Salt & Iminium Salt & Aminal & $\begin{array}{c}\text { Transition } \\
\text { State }\end{array}$ & Product \\
\hline & B3LYP/ & 0 & 7.9 & 17.6 & -5.0 & 18.0 & -5.1 \\
\hline$A->9$ & $6-31+G(d)$ & 0 & 9.2 & 19.7 & 11.1 & 33.8 & 12.4 \\
\hline \multirow{2}{*}{ B3LYP } & B3LYP-D3/ & 0 & 7.7 & 17.0 & -12.9 & 7.5 & -17.5 \\
\hline & $6-31+G(d)$ & 0 & 9.9 & 19.4 & 3.5 & 24.3 & 1.3 \\
\hline \multirow{2}{*}{$\begin{array}{c}\text { A -> } 9 \\
\omega B 97 X D\end{array}$} & $\omega B 97 X-D a n d /$ & 0 & 7.8 & 16.6 & -17.1 & 6.8 & -22.5 \\
\hline & $6-31+G(d)$ & 0 & 9.3 & 18.4 & -0.5 & 22.9 & -3.6 \\
\hline \multirow{4}{*}{$\begin{array}{l}7 \text {-> B } \\
\text { B3LYP }\end{array}$} & B3LYP/ & 0 & 7.8 & 16.4 & -7.1 & 12.7 & -3.3 \\
\hline & $6-31+G(d)$ & 0 & 9.3 & 18.3 & 9.9 & 28.3 & 12.5 \\
\hline & B3LYP-D3/ & 0 & 7.9 & 15.9 & -16.1 & 3.0 & -14.4 \\
\hline & $6-31+G(d)$ & 0 & 9.4 & 17.4 & 2.7 & 19.9 & 4.8 \\
\hline \multirow{2}{*}{$\begin{array}{c}7->\mathbf{B} \\
\omega B 97 X D\end{array}$} & $\omega B 97 X-D a n d /$ & 0 & 4.2 & 7.6 & -20.5 & 5.6 & -19.0 \\
\hline & $6-31+G(d)$ & 0 & 6.1 & 9.4 & -3.2 & 22.8 & -0.5 \\
\hline
\end{tabular}


The structure of ethylenediamine derivative $8 b$ has been confirmed by single crystal X-ray analysis (Figures 4 and 5). The symmetrical internal quaternary salt $\mathbf{8 b}$ crystallizes as a pentahydrate. The asymmetric part of the unit cell consists of two halves of $\mathbf{8 b}$ occupying special positions of $C_{i}$ symmetry, two molecules of $\mathbf{8 b}$ adopting a non-crystallographic $\mathrm{C}_{\mathrm{i}}$-symmetric conformation and located in general positions and 15 water molecules. The $-\mathrm{CH}_{2}-\mathrm{N}-\mathrm{CH}_{2}-\mathrm{CH}_{2}-\mathrm{N}-\mathrm{CH}_{2}$ - fragment of all molecules is fully extended. In crystal, $\pi-\pi$ stacking interactions between the quinoline systems of $\mathbf{8 b}$ organize the molecules into two symmetry independent columns along the [11-1] direction. The water molecules forming a $1 \mathrm{D}$ assembly via O-H.O hydrogen bond along [11-1] occupy a channel formed between four such columns and bind to the carboxylate groups of $\mathbf{8 b}$ (Figure 5). Since ${ }^{1} \mathrm{H}$ NMR spectra of compounds $\mathbf{8 a}, \mathbf{b}$ and $\mathbf{9}$ reveal single molecules, the absolute configurations at the quaternary nitrogen atoms in $\mathbf{8 a}$ and $\mathbf{9}$ have been assigned analogously to the meso isomer $\mathbf{8 b}$, for which $2 \mathrm{R} 2$ 'S configuration has been proven by single crystal $\mathrm{X}$-ray analysis. However, it cannot be ruled out that the reaction mechanisms that underlay the formation of compounds $8 \mathbf{a}$ and $\mathbf{9}$ are different to that of $\mathbf{8 b}$, and hence, these derivatives are obtained as pure enantiomers or their racemic mixtures.

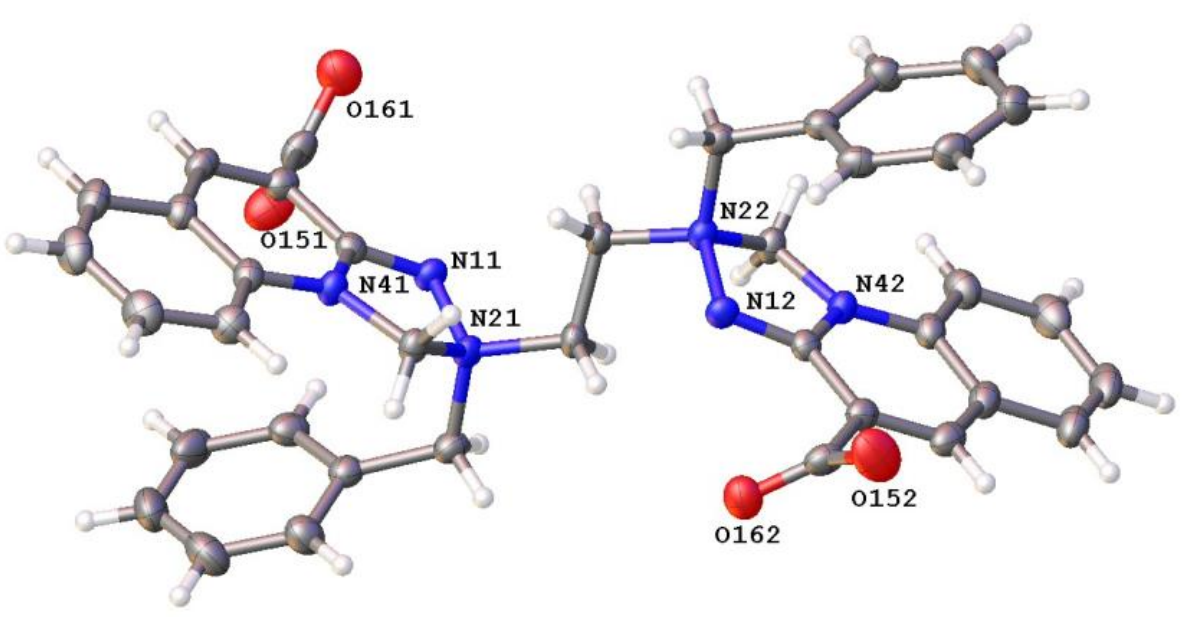

Figure 4. Molecular structure of Safirinium Q dimer $\mathbf{8 b}$. Displacement ellipsoids are shown at the $50 \%$ probability level. Only one of the four symmetry independent molecules of $\mathbf{8 b}$ is shown.

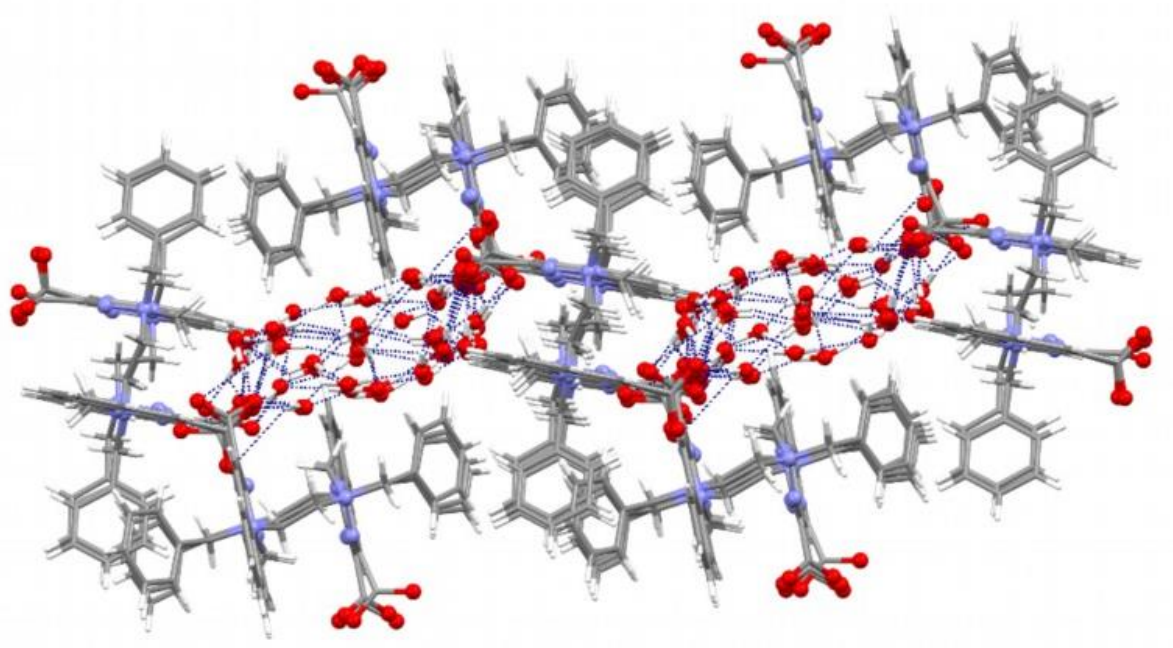

Figure 5. Crystal packing in $\mathbf{8 b}$ showing columns of $\mathbf{8 b}$ via $\pi-\pi$ stacking interactions and water channels. 


\section{Conclusions}

In summary, we have shown that isoxazolo[3,4-b]pyridin-3(1H)-ones form hemiaminals with formaldehyde at the N1 nitrogen atoms. The results of theoretical studies carried out using DFT and PCM methods indicate that the same reaction performed in the presence of secondary amine leads to thermodynamically favored 2,3-dihydro-[1,2,4]triazolo[4,3a]pyridin-2-ium-8-carboxylates (Safirinium dyes). It was demonstrated that theoretical replication of previously reported reactivity of isoxazolones, i.e., the tandem Mannichelectrophilic amination reaction, can be accomplished by application of B3LYP functional augmented with Grimme's empirical dispersion (B3LYP-D3), as well utilization of rangeseparated hybrid functional $\omega B$ B7X-Dand. Furthermore, it was demonstrated that diastereoselectivity of the tandem reactions involving L-proline results from asymmetric LUMO distribution within the iminium salt. Finally, the performed experiments with a set of ethylenediamine derivatives proved that the studied tandem reactivity of isoxazolones with secondary amines is of a general nature and can be only hampered in sterically constrained starting materials such as $\mathrm{N}$-substituted piperazine.

\section{Experimental}

\subsection{Chemistry}

\subsubsection{Materials and Methods}

Chemicals were obtained from commercial sources and were used without further purification. All NMR experiments were performed at $25{ }^{\circ} \mathrm{C}$ on Bruker Avance II HD $400 \mathrm{MHz}$ spectrometer. ${ }^{1} \mathrm{H}$ NMR data were internally referenced to $\mathrm{CD}_{3} \mathrm{OD}$ (3.31 ppm), DMSO-D $_{6}(2.50 \mathrm{ppm})$ or TMS (0.00 ppm). The IR (KBr pellets) spectra were recorded on a Thermo Scientific Nicolet 380 FT-IR spectrometer. The mass spectra were recorded on a Shimadzu single quadrupole LCMS 2010 EV mass spectrometer. Melting points were determined on an X-4 melting point apparatus with a microscope and were uncorrected. Elemental analysis was performed with Vario El Cube CHNS, Elementar. Analytical TLC was performed on silica gel Merck $60 \mathrm{~F} 254$ plates $(0.25 \mathrm{~mm})$ with UV light visualization (mobile phase: $\mathrm{CHCl}_{3} / \mathrm{MeOH}$ 0.9:0.1 v/v). 4,6-Dimethylisoxazolo[3,4-b]pyridin-3(1H)one (1) and isoxazolo[3,4-b]quinolin-3(1H)-one (4) were obtained according to previously described procedures $[3,4,20]$.

4.1.2. Synthesis of 1-(hydroxymethyl)-4,6-dimethylisoxazolo[3,4-b]pyridin-3(1H)-one (2) and 1-(hydroxymethyl)isoxazolo[3,4-b] quinolin-3(1H)-one (5)

4,6-Dimethylisoxazolo[3,4-b]pyridin-3(1H)-one (1) or isoxazolo[3,4-b]quinolin-3(1H)one (4) (1.9 mmol, 312 or $354 \mathrm{mg}$, respectively) was dissolved in methanol $(20 \mathrm{~mL})$, then $35 \%$ water solution of formaldehyde $(0.60 \mathrm{~mL}, 7.6 \mathrm{mmol})$ was added and the resulting mixture was stirred for $4 \mathrm{~h}$ at room temperature. The precipitated solid was filtered off, washed with diethyl ether $(3 \times 5 \mathrm{~mL})$ and recrystallized from methanol prior to characterization.

1-(Hydroxymethyl)-4,6-dimethylisoxazolo[3,4-b]pyridin-3(1H)-one (2). Yield: $80 \%$ (0.296 g); m.p. $201-202{ }^{\circ} \mathrm{C}^{1}{ }^{1} \mathrm{H}$ NMR $\left(300 \mathrm{MHz}, \mathrm{CD}_{3} \mathrm{OD}\right): \delta=2.58\left(\mathrm{~s}, 3 \mathrm{H}, \mathrm{CH}_{3}\right), 2.60(\mathrm{~s}$, $\left.3 \mathrm{H}, \mathrm{CH}_{3}\right), 5.29$ (s, 2H, $\left.\mathrm{CH}_{2}\right), 7.04(\mathrm{~s}, 1 \mathrm{H}, \mathrm{CH})$; IR (KBr): 3383, 3003, 2960, 2842, 1748, 1616, 1590, 1445, 1371, 1177, 1061, 1034, 998, 883, 864, 805, 706, 656, $638 \mathrm{~cm}^{-1}$; MS (ESI) m/z: $195[\mathrm{M}+1]^{+}$.

1-(Hydroxymethyl)isoxazolo[3,4-b]quinolin-3(1H)-one (5). Yield: 54\% (0.222 g); m.p. 237-242 ${ }^{\circ} \mathrm{C} ;{ }^{1} \mathrm{H}$ NMR $\left(300 \mathrm{MHz}, \mathrm{DMSO}-\mathrm{D}_{6}\right): \delta=4.79(\mathrm{bs}, 1 \mathrm{H}, \mathrm{OH}), 5.31\left(\mathrm{~d}, 2 \mathrm{H}, \mathrm{CH}_{2}\right), 7.65$ $(\mathrm{t}, \mathrm{J}=8.1 \mathrm{~Hz}, 1 \mathrm{H}, \mathrm{CH}), 7.79(\mathrm{t}, \mathrm{J}=8.1 \mathrm{~Hz}, 1 \mathrm{H}, \mathrm{CH}), 8.03(\mathrm{~d}, \mathrm{~J}=8,1 \mathrm{~Hz}, 1 \mathrm{H}, \mathrm{CH}), 8.23(\mathrm{~d}$, $\mathrm{J}=8,1 \mathrm{~Hz}, 1 \mathrm{H}, \mathrm{CH}), 9.20$ (s, 1H, CH); IR (KBr): 3302, 2921, 1771, 1627, 1506, 1427, 1356, 1171, 1125, 1090, 1057, 1028, 989, 934, 891, $766 \mathrm{~cm}^{-1}$; MS (ESI) m/z: $217[\mathrm{M}+1]^{+}$.

\subsubsection{Synthesis of $[1,2,4]$ triazolo[4,3-a]quinolin-2-ium-4-carboxylates (7-9)}

Isoxazolo[3,4-b]quinolin-3(1H)-one $(354 \mathrm{mg}, 1.9 \mathrm{mmol})$ was dissolved in methanol $(20 \mathrm{~mL})$, then $35 \%$ water solution of formaldehyde $(0.60 \mathrm{~mL}, 7.6 \mathrm{mmol})$ and $0.85 \mathrm{mmol}$ of the corresponding amine was added (piperazine, homopiperazine, $N, N^{\prime}$-dimethylethylenedia 
mine or $N, N^{\prime}$-dibenzylethylenediamine). The mixture was stirred for $5 \mathrm{~min}$ at room temperature. The progress of the reaction was monitored by TLC. The mixture was evaporated under reduced pressure when the red color of the substrate disappeared. The resulting solid was washed with acetone $(3 \times 5 \mathrm{~mL})$. In the case of compound 7 , an additional equivalent $(0.85 \mathrm{mmol})$ of piperazine was added since red isoxazolo[3,4b]quinolin-3 $(1 H)$-one was still present in the reaction mixture after $24 \mathrm{~h}$ of stirring.

$1 H$-Spiro[1,2,4]triazolo[4,3-a]quinoline-2,1'-piperazin]-2-ium-4-carboxylate (7). Yield: $43 \%$ (0.232 g); m.p. 207-209 ${ }^{\circ} \mathrm{C} ;{ }^{1} \mathrm{H}$ NMR (400 MHz, CD $\left.3 \mathrm{OD}\right): \delta=3.18-3.35\left(\mathrm{~m}, 2 \mathrm{H}, \mathrm{CH}_{2}\right)$, 3.52-3.58 (m, 2H, $\left.\mathrm{CH}_{2}\right), 5.91\left(\mathrm{~s}, 4 \mathrm{H}, \mathrm{CH}_{2}\right), 7.21(\mathrm{~d}, 2 \mathrm{H}, \mathrm{J}=8.1 \mathrm{~Hz}, \mathrm{CH}), 7.35(\mathrm{t}, 2 \mathrm{H}, \mathrm{J}=8.1 \mathrm{~Hz}$, $\mathrm{CH})$, 7.87-7.72 (m, 2H, CH), 8.10 (s, 2H, CH); IR (KBr): 3408, 3264, 3040, 2997, 2956, 2918, 2848, 1633, 1589, 1569, 1541. 1457, 1353, 1297, 1223, 806, $761 \mathrm{~cm}^{-1}$; MS (ESI) m/z: 285 $[\mathrm{M}+1]^{+}$.

(2R,2'S)-2,2' -(Ethane-1,2-diyl)bis(2-methyl-1,2-dihydro-[1,2,4]triazolo[4,3-a]quinolin-2ium-4-carboxylate) (8a). The product, which was obtained in the form of inner salt, was quantitatively converted into a hydrochloride form to increase its solubility. Hence, prior to spectral analysis, the solid was dissolved in $\mathrm{MeOH}$, acidified to $\mathrm{pH} 3-4$ with methanolic $\mathrm{HCl}$ solution and the resulting solution was evaporated under reduced pressure to give 2,2' -(ethane-1,2-diyl)bis(4-carboxy-2-methyl-1,2-dihydro-[1,2,4]triazolo[4,3-a]quinolin2-ium) dichloride. Yield: 72\% (0.340 g); m.p. $237-239{ }^{\circ} \mathrm{C} ;{ }^{1} \mathrm{H}$ NMR (400 MHz, DMSO-D 6 ): $\delta=3.33\left(\mathrm{~s}, 3 \mathrm{H}, \mathrm{CH}_{3}\right), 4.51-4.60\left(\mathrm{~m}, 4 \mathrm{H}, \mathrm{CH}_{2}\right), 6.04\left(\mathrm{~d}, \mathrm{~J}^{2}=8.9 \mathrm{~Hz}, 2 \mathrm{H}, \mathrm{CH}_{2}\right), 6.20(\mathrm{~d}$, $\left.\mathrm{J}^{2}=8.9 \mathrm{~Hz}, 2 \mathrm{H}, \mathrm{CH}_{2}\right), 7.22(\mathrm{~d}, 2 \mathrm{H}, \mathrm{J}=7.9 \mathrm{~Hz}, \mathrm{CH}), 7.43(\mathrm{t}, 2 \mathrm{H}, \mathrm{J}=7.9 \mathrm{~Hz}, \mathrm{CH}), 7.84(\mathrm{t}, 2 \mathrm{H}$, $\mathrm{J}=7.9 \mathrm{~Hz}, \mathrm{CH}), 8.06$ (d, 2H, J = 7.9 Hz, CH), 8.80 (s, 2H, CH); IR (KBr): 3438, 3055, 3021, 2967, 1723, 1616, 1571, 1541, 1456, 1313, 1222, 1200, 1167, 784, 765, 746, $705 \mathrm{~cm}^{-1}$; MS (ESI) $\mathrm{m} / \mathrm{z}: 243[(\mathrm{M}+2) / 2]^{2+}, 485[\mathrm{M}+1]^{+}$.

(2R,2'S)-2,2'-(Ethane-1,2-diyl)bis(2-benzyl-1,2-dihydro-[1,2,4]triazolo[4,3-a] quinolin-2ium-4-carboxylate) (8b). Yield: 79\% (0.49 g); m.p. $156-157^{\circ} \mathrm{C} ;{ }^{1} \mathrm{H}$ NMR $\left(400 \mathrm{MHz}, \mathrm{CD}_{3} \mathrm{OD}\right)$ : $\delta=4.61-4.76\left(\mathrm{~m}, 4 \mathrm{H}, \mathrm{CH}_{2}\right), 4.95\left(\mathrm{~s}, 4 \mathrm{H}, \mathrm{CH}_{2}\right), 6.08\left(\mathrm{~d}, \mathrm{~J}^{2}=9.6 \mathrm{~Hz}, 1 \mathrm{H}, \mathrm{CH}_{2}\right), 6.19(\mathrm{~d}$, $\left.\mathrm{J}^{2}=9.6 \mathrm{~Hz}, 1 \mathrm{H}, \mathrm{CH}_{2}\right), 7.12-7.17(\mathrm{~m}, 8 \mathrm{H}, \mathrm{CH}), 7.33(\mathrm{t}, 2 \mathrm{H}, \mathrm{J}=7.7 \mathrm{~Hz}, \mathrm{CH}), 7.59-7.62(\mathrm{~m}$, $4 \mathrm{H}, \mathrm{CH}), 7.67(\mathrm{t}, 2 \mathrm{H}, \mathrm{J}=8.3 \mathrm{~Hz}, \mathrm{CH}), 7.71(\mathrm{~d}, 2 \mathrm{H}, \mathrm{J}=7.7 \mathrm{~Hz}, \mathrm{CH}), 8.23(\mathrm{~s}, 2 \mathrm{H}, \mathrm{CH})$; IR (KBr): 3407, 3064, 3020, 1627, 1586, 1570, 1541, 1458, 1376, 1224, 807, 759, 705, 669, $595 \mathrm{~cm}^{-1}$; MS (ESI) m/z: $319[(\mathrm{M}+2) / 2]^{2+}, 637[\mathrm{M}+1]^{+}$; elemental analysis: calcd. (\%) for (\%) $\mathrm{C}_{38} \mathrm{H}_{32} \mathrm{~N}_{6} \mathrm{O}_{4} \times 5 \mathrm{H}_{2} \mathrm{O}$ : C 62.80, $\mathrm{H}$ 5.82, N 11.56; found C 62.65, H 5.79, $\mathrm{N} 11.70$.

(2S,2" S)-Dispiro[1H-[1,2,4] triazolo[4,3-a]quinoline-2,1'-[1,4]diazepan]-4' ,2"-1H-1,2, 4]triazolo[4,3-a]quinoline]-1' ${ }^{\prime} 4^{\prime}$-diium-4,4"-dicarboxylate (9). Yield: 79\% (0.373 g); m.p. 212-213 ${ }^{\circ} \mathrm{C} ;{ }^{1} \mathrm{H}$ NMR (400 MHz, CD $\left.3 \mathrm{OD}\right): \delta=2.81-2.86\left(\mathrm{~m}, 2 \mathrm{H}, \mathrm{CH}_{2}\right), 4.19-5.36(\mathrm{~m}, 6 \mathrm{H}$, $\left.\mathrm{CH}_{2}\right), 5.29\left(\mathrm{~d}, \mathrm{~J}=14.9 \mathrm{~Hz}, 2 \mathrm{H}, \mathrm{CH}_{2}\right), 5.98\left(\mathrm{~d}, \mathrm{~J}^{2}=8.4 \mathrm{~Hz}, 2 \mathrm{H}, \mathrm{CH}_{2}\right), 6.14\left(\mathrm{~d}, \mathrm{~J}^{2}=8.4 \mathrm{~Hz}\right.$, $\left.2 \mathrm{H}, \mathrm{CH}_{2}\right), 7.24(\mathrm{~d}, 2 \mathrm{H}, \mathrm{J}=7.8 \mathrm{~Hz}, \mathrm{CH}), 7.40(\mathrm{t}, 2 \mathrm{H}, \mathrm{J}=7.8 \mathrm{~Hz}, \mathrm{CH}), 7.75(\mathrm{t}, 2 \mathrm{H}, \mathrm{J}=7.8 \mathrm{~Hz}$, $\mathrm{CH}), 7.84$ (d, 2H, J = 7.8 Hz, CH), 8.37 (s, 2H, CH); IR (KBr): 3442, 3004, 1637, 1587, 1568, $1533,1456,1399,1351,1337,1225,807,762,744 \mathrm{~cm}^{-1}$; MS (ESI) m/z: $249[(\mathrm{M}+2) / 2]^{2+}, 497$ $[\mathrm{M}+1]^{+}$.

\subsection{Theoretical Calculations}

All theoretical calculations have been completed with the Gaussian 16 [14] package pursuant to the following methodological procedure. For each chemical entity, the groundstate structure has been obtained by a standard force-minimization process using default G16 thresholds and algorithms. The vibrational spectra have been obtained to systematically check that all vibrational frequencies are real. Thus, each stationary point was characterized by a frequency calculation, starting materials, intermediates and products proving all positive frequencies and transition structures featuring a single negative (imaginary) frequency. The vibrational mode pertaining to the negative frequency was animated in each case to confirm that it matched to the presumed concerted bond-making/breaking mechanism. The transition states were also affirmed by intrinsic reaction coordinate (IRC) calculations. The standard hybrid Becke-3-Lee-Yang-Parr functional (B3LYP) [11] with and without Grimme's empirical dispersion (GD3) [15,16], as well as range-separated hybrid 
functional $\omega$ B97X-Dand [12], were utilized for these calculations. The bulk solvent effects were taken into account for the DFT calculations by means of a Polarizable Continuum Model (IEF-PCM) [13]. Standard basis sets, i.e., 6-31+G(d) and 6-311+G(d,p), have been used in the course of this project. The energies reported are given relative to the most stable conformers of the reactants. Gibbs free energies $(\Delta \mathrm{G})$ including zero point correction, temperature correction, and vibrational energy were computed for standard conditions ( $\mathrm{T}=298.15 \mathrm{~K}, \mathrm{P}=1.0 \mathrm{~atm})$ using the harmonic oscillator approximation.

\subsection{X-ray Crystallography}

Diffraction experiments were carried out at room temperature with an Oxford Diffraction Xcalibur E diffractometer using Mo K $\alpha$ radiation for 2 and at $131 \mathrm{~K}$ with an Oxford Diffraction SuperNova diffractometer using $\mathrm{Cu} K \alpha$ radiation for $\mathbf{8 b}$. Diffraction data were processed with CrysAlisPro software [21]. In case of $\mathbf{2}$ the structure was determined from a twinned specimen. The structures were solved with the program SHELXT [22] and refined by full-matrix least-squares method on $F^{2}$ with SHELXL-2018/3 [23] within the Olex2 software [24]. Hydrogen atoms were placed in calculated positions and refined as riding on their carriers, except that of the O-H group in $\mathbf{2}$ which was freely refined. CCDC 2082365-2082366 contain the supplementary crystallographic data for this paper. These data can be obtained free of charge via http://www.ccdc.cam.ac.uk/conts/retrieving.html (or from the CCDC, 12 Union Road, Cambridge CB2 1EZ, UK; Fax: +44-1223-336033; E-mail: deposit@ccdc.cam.ac.uk).

Crystal data for $2\left(\mathrm{C}_{11} \mathrm{H}_{10} \mathrm{NO}, M=172.20 \mathrm{~g} / \mathrm{mol}\right)$ : triclinic, space group P-1 (no. 2), $a$ $=7.7520(6) \AA, b=7.9402(6) \AA, c=8.0287(7) \AA, \alpha=75.284(7)^{\circ}, \beta=70.571(7)^{\circ}, \gamma=81.744(6)^{\circ}$, $V=449.81(7) \AA^{3}, Z=2, T=293(2) \mathrm{K}, \mu(\mathrm{Mo} \mathrm{K} \alpha)=0.082 \mathrm{~mm}^{-1}, D_{\text {calc }}=1.271 \mathrm{~g} / \mathrm{cm}^{3}, 9045$ reflections measured $\left(6.52^{\circ} \leq 2 \Theta \leq 50.02^{\circ}\right)$, unique $3294\left(R_{\text {int }}=0.031, R_{\text {sigma }}=0.0292\right)$ which were used in all calculations. The final $R_{1}$ was $0.0361(\mathrm{I}>2 \sigma(\mathrm{I}))$ and $w R_{2}$ was 0.0893 (all data). Hydrogen atoms of the methyl groups are disordered due to the rotation of the methyl group around the $\mathrm{C}-\mathrm{C}$ bond. The molecule of $\mathbf{2}$ is shown in Figure 1.

Crystal data for $8 \mathbf{b}\left(\mathrm{C}_{38} \mathrm{H}_{32} \mathrm{~N}_{6} \mathrm{O}_{4} \cdot 5 \mathrm{H}_{2} \mathrm{O}, M=726.77 \mathrm{~g} / \mathrm{mol}\right)$ : triclinic, space group P-1 (no. 2), $a=16.5969(5) \AA, b=18.1134(4) \AA, c=19.4666(6) \AA, \alpha=104.252(2)^{\circ}, \beta=95.940(3)^{\circ}$, $\gamma=105.512(2)^{\circ}, V=5374.9(3) \AA^{3}, Z=6, T=131 \mathrm{~K}, \mu(\mathrm{CuK} \alpha)=0.806 \mathrm{~mm}^{-1}, D_{\text {calc }}=1.347$ $\mathrm{g} / \mathrm{cm}^{3}, 52232$ reflections measured $\left(4.762^{\circ} \leq 2 \Theta \leq 136.5^{\circ}\right), 19659$ unique $\left(R_{\text {int }}=0.0341\right.$, $\left.R_{\text {sigma }}=0.0394\right)$ which were used in all calculations. The final $R_{1}$ was $0.0563(\mathrm{I}>2 \sigma(\mathrm{I}))$ and $w R_{2}$ was 0.1561 (all data). One of the carboxylate groups and one of the ethylene bridges are disordered over two sites. The molecule of $\mathbf{8 b}$ is shown in Figure 4.

Author Contributions: Conceptualization, J.S. and J.F.; methodology, J.S. and M.G.; software, J.S. and M.G.; validation, J.S., J.F., P.W. and M.G.; formal analysis, J.S. and M.G.; investigation, J.S., J.F., P.W. and M.G.; resources, J.S.; data curation, J.S. and M.G.; writing—original draft preparation, J.S. and M.G.; writing —review and editing, J.S. and M.G.; visualization, J.S. and M.G.; supervision, J.S.; project administration, J.S.; funding acquisition, J.S. All authors have read and agreed to the published version of the manuscript.

Funding: This work partially supported by Polish Ministry of Science and Higher Education and National Science Centre, research grant IP2012 055472.

Institutional Review Board Statement: Not applicable.

Informed Consent Statement: Not applicable.

Data Availability Statement: Not applicable.

Acknowledgments: Not applicable.

Conflicts of Interest: The authors declare no conflict of interest. 


\section{References}

1. Kolb, H.C.; Sharpless, K.B. The growing impact of click chemistry on drug discovery. Drug Discov. Today 2003, 8, $1128-1137$. [CrossRef]

2. Kolb, H.C.; Finn, M.G.; Sharpless, K.B. Click Chemistry: Diverse Chemical Function from a Few Good Reactions. Angew. Chem. Int. Ed. 2001, 40, 2004-2021. [CrossRef]

3. Fedorowicz, J.; Saczewski, J.; Drażba, Z.; Wiśniewska, P.; Gdaniec, M.; Wicher, B.; Suwiński, G.; Jalińska, A. Synthesis and fluorescence of dihydro-[1,2,4]triazolo[4,3-a]pyridin-2-iumcarboxylates: An experimental and TD-DFT comparative study. Dyes Pigm. 2019, 161, 347-359. [CrossRef]

4. Saczewski, J.; Hinc, K.; Obuchowski, M.; Gdaniec, M. The tandem Mannich-electrophilic amination reaction: A versatile platform for fluorescent probing and labelling. Chem. Eur. J. 2013, 19, 11531-11535. [CrossRef] [PubMed]

5. Fedorowicz, J.; Cebrat, M.; Wierzbicka, M.; Wiśniewska, P.; Jalińska, A.; Dziomba, S.; Gdaniec, M.; Jaremko, M.; Jaremko, L.; Chandra, K.; et al. Synthesis and evaluation of dihydro-[1,2,4]triazolo[4,3-a]pyridin-2-ium carboxylates as fixed charge fluorescent derivatization reagents for MEKC and MS proteomic analyses. J. Mol. Str. 2020, 1217, 128426. [CrossRef]

6. Kraft, O.; Kozubek, M.; Hoenke, S.; Serbian, I.; Major, D.; Csuk, R. Cytotoxic triterpenoid-safirinium conjugates target the endoplasmicreticulum. Eur. J. Med. Chem. 2019, 209, 112920. [CrossRef]

7. Fedorowicz, J.; Wierzbicka, M.; Cebrat, M.; Wiśniewska, P.; Piątek, R.; Zalewska-Piątek, B.; Szewczuk, Z.; Saczewski, J. Application of Safirinium N-Hydroxysuccinimide Esters to Derivatization of Peptides for High-Resolution Mass Spectrometry, Tandem Mass Spectrometry, and Fluorescent Labeling of Bacterial Cells. Int. J. Mol. Sci. 2020, 21, 9643. [CrossRef]

8. Cervantes, C.; Mora, J.R.; Marquez, E.; Torres, J.; Rincón, L.; Mendez, M.A.; Alcázar, J.J. Theoretical Calculations of the Multistep Reaction Mechanism Involved in Asparagine Pyrolysis Supported by Degree of Rate Control and Thermodynamic Control Analyses. Appl. Sci. 2019, 9, 4847. [CrossRef]

9. Saielli, G. TD-DFT Prediction of the Intermolecular Charge-Transfer UV-Vis Spectra of Viologen Salts in Solution. Appl. Sci. 2020 10, 8108. [CrossRef]

10. Friães, S.; Lima, E.; Boto, R.E.; Ferreira, D.; Fernandes, J.R.; Ferreira, L.F.V.; Silva, A.M.; Reis, L.V. Photophysicochemical Properties and In Vitro Phototherapeutic Effects of Iodoquinoline- and Benzothiazole-Derived Unsymmetrical Squaraine Cyanine Dyes. Appl. Sci. 2019, 9, 5414. [CrossRef]

11. Becke, A.D. Density-functional thermochemistry. III. The role of exact exchange. J. Chem. Phys. 1993, 98, 5648-5652. [CrossRef]

12. Chai, J.-D.; Head-Gordon, M. Systematic optimization of long-range corrected hybrid density functionals. J. Chem. Phys. 2008, 128, 084106. [CrossRef] [PubMed]

13. Tomasi, J.; Mennucci, B.; Cammi, R. Quantum mechanical continuum solvation models. Chem. Rev. 2005, 105, 2999-3094. [CrossRef] [PubMed]

14. Gaussian 16, Revision A.03; Gaussian, Inc.: Wallingford, CT, USA, 2016.

15. Grimme, S.; Antony, J.; Ehrlich, S.; Krieg, H. A consistent and accurate ab initio parametrization of density functional dispersion correction (DFT-D) for the 94 elements H-Pu. J. Chem. Phys. 2010, 130, 154104. [CrossRef] [PubMed]

16. Gansäuer, A.; Seddiqzai, M.; Dahmen, T.; Sure, R.; Stefan Grimme, S. Computational study of the rate constants and free energies of intramolecular radical addition to substituted anilines. Beilstein J. Org. Chem. 2013, 9, 1620-1629. [CrossRef] [PubMed]

17. Groom, C.R.; Bruno, I.J.; Lightfoot, M.P.; Ward, S.C. The Cambridge Structural Database. Acta Cryst. 2016, B72, 171-179. [CrossRef] [PubMed]

18. Gawdzik, B.; Iwanek, W. Synthesis, structure, and stereochemistry of the bora derivativesof 1-[(2-hydroxy-1-naphthyl)methyl]proline. Tetrahedron Asymmetry 2005, 16, 2019-2023. [CrossRef]

19. Fedorowicz, J.; Saczewski, J.; Konopacka, A.; Waleron, K.; Lejnowski, D.; Ciura, K.; Tomasic, T.; Skok, Z.; Savijoki, K.; Morawska, M.; et al. Synthesis and biological evaluation of hybrid quinolone-based quaternary ammonium antibacterial agents. Eur. J. Med. Chem. 2019, 179, 576-590. [CrossRef]

20. Sączewski, J.; Fedorowicz, J.; Korcz, M.; Sączewski, F.; Wicher, B.; Gdaniec, M.; Konopacka, A. Experimental and theoretical studies on the tautomerism and reactivity of isoxazolo[3,4-b]quinolin-3(1H)-ones. Tetrahedron 2015, 71, 8975-8984. [CrossRef]

21. Rigaku Oxford Diffraction. Crys AlisPro Software System, Version 1.171.38.43c; Rigaku Corporation: Oxford, UK, 2015.

22. Sheldrick, G.M. SHELXT-Integrated Space-Group and Crystal-Structure Determination. Acta Cryst. 2015, A71, 3-8. [CrossRef]

23. Sheldrick, G.M. Crystal structure refinement with SHELXL. Acta Cryst. 2015, C71, 3-8. [CrossRef]

24. Dolomanov, O.V.; Bourhis, L.J.; Gildea, R.J.; Howard, J.A.K.; Puschmann, H. OLEX2: A complete structure solution, refinement and analysis program. J. Appl. Cryst. 2009, 42, 339-341. [CrossRef] 